\title{
CHRISTINA ROSSETTI'S RADICAL OBJECTIVITY
}

\section{By Ashley Miller}

FOR DECADES NOW, CHRISTINA Rossetti's poetry has proven to be a rich vantage point from which to explore the complexity of Victorian attitudes toward the material world. This is certainly true of her most famous poem, "Goblin Market." Deliciously steeped in the sensual experiences it simultaneously condemns, "Goblin Market" is a poem invested - ambiguously, for most critics - in the relationship between humans and material things: the things they buy, look at, feel, taste. This is a relationship we tend to consider in terms of commodity culture and economic exchange. And such a reading makes sense: Rossetti's poem, a tale of two sisters whose domesticity is disrupted by the tramp of mysterious goblin men selling fruit from unknown climes, grapples in many ways with these exact terms. Laura (who barters a lock of hair for the goblin fruit and then begins to waste away from an insatiable appetite) and Lizzie (who saves her sister by bringing home an antidote in the form of fruit juice, which she herself has refused to consume) seem to embody the potential dangers faced by the female consumer. Indeed, so much has been written about the relationship between women and consumer culture in "Goblin Market" that it nearly qualifies as its own subfield in Victorian studies.

Much of this vast body of scholarship, though, is motivated by a central concern: debating whether entry into the marketplace - into the world of economic exchange - is necessarily dangerous for women. ${ }^{1}$ Does Rossetti condemn the sisters' marketing, or does she slyly celebrate it? On one side of the debate, Laura's fall is read in line with what critics call Rossetti's aesthetics of renunciation, her religious demand to withdraw from the material world. It's hard to ignore the overtones of prostitution inherent in Laura's bartering of her own hair - an extension of her body - in order to enter the marketplace. For critics like Elizabeth Helsinger who read the marketplace as ultimately dangerous for women, Lizzie becomes the poem's heroine because "she gets what she wants without giving in to the pressure that a male marketplace, like male texts about the marketplace, exerts on women - to become that which is exchanged, to become money" $(923) .^{2}$ On the other side are critics who identify Rossetti's poem as radical because of the way it "affirms female desire" within the public marketplace, as Krista Lysack writes (18). For Lysack, "Goblin Market" emphasizes the pleasures of the market by imagining an economy in which "women consume but are not consumed, look but do not buy" (18). ${ }^{3}$ In debates about gender and exchange, then, much depends upon whether the activity of female consumption can occur without women themselves being objects of consumption. Becoming the thing that is consumed, in both readings of the poem, necessarily indicates a loss of agency. 
But what would it look like to read "Goblin Market" without assuming that "being like a thing" (and I'm borrowing here from Elaine Freedgood) is necessarily bad? Rather than enter fully into the ongoing debate about gender and exchange, I want instead to reexamine the terms of agency and objectivity upon which it relies. In doing so I build upon Lorraine Janzen Kooistra's insightful reading of visibility and perception in "Goblin Market," which makes note of Lizzie's ability to "see men looking at her" without forfeiting her subjectivity (141). These "dynamics of looking," in Kooistra's account, "radically challenge the binary opposition between active male 'see-er' and passive female 'seen'" (141). In what follows I want to further develop the challenge that Kooistra identifies, but I also want to complicate it by noting that, for Rossetti, seeing and being seen are not so easily equated with activity and passivity to begin with. Instead, looking (rather than being looked at) is itself implicated in a kind of loss of agency. In "Goblin Market," perception functions as a kind of economy itself - a system of interaction and exchange - and in this economy of perception, the object one perceives may have power over the one who perceives it. From this vantage point, "Goblin Market" is less a poem about retaining subjectivity than it is one about acquiring objectivity.

My aim here is to explore this disorienting perspective. In "Goblin Market" and elsewhere, I argue, Rossetti constructs a world in which subjective perception is threatening and in which things can hold positions of surprising power. In order make this claim, I'll engage an increasingly important topic in recent criticism: Victorian relations between humans and nonhuman objects. I'm interested in this relationship both as it appears in contemporary scholarship and as it appears in the work of one of Rossetti's contemporaries, John Ruskin. Ruskin's aggressive antipathy to relativist models of sense perception leads him to posit, in his 1856 essay "Of the Pathetic Fallacy," a potentially radical theory of objects. Much like "Goblin Market," Ruskin's model of perception interrogates the problem of taste as an especially private, subjective experience. And much like "Goblin Market," Ruskin imagines an economy of perception in which objects hold power over perceiving subjects. My goal is not to establish any kind of direct line of influence between Ruskin and Rossetti, though they certainly moved in overlapping circles. Instead, what Ruskin offers me here is a chance to articulate a kind of Victorian object theory - one that resembles, in many ways, recent theories of human-object relations posited by Bill Brown, Elaine Freedgood, Jane Bennett, and others - and then to use that Ruskinian object theory to unpack some of the ways in which Rossetti's poetry and prose demonstrate particular concerns about perception and objectivity. This paper, then, moves first through an exploration of Ruskin's rhetoric of powerful things before turning (at greater length) to Rossetti, with this end in mind: exploring Rossetti's radical objectivity, I argue, helps us gain new purchase on the complex constellation of bodies, things, and power that underwrites so much of her provocative corpus.

\section{Ruskin's powerful things}

MUCH OF JOHN RUSKIN'S AESTHETIC theory hinges on defining truth against falseness, the way things are against the way we may inaccurately perceive or portray them. These structures, too, underlie Ruskin's major contribution to poetics: the concept of the pathetic fallacy, introduced in Modern Painters III (subtitled, somewhat coyly, "Of Many Things"). As J. Hillis Miller has argued, the pathetic fallacy is a variation on personification. But what 
is at stake here - the truth that needs to be defended against inaccurate representation - is the innate power of the object in the economy of perception. Ruskin defines the pathetic fallacy as "a falseness in all our impressions of external things," the result of "violent feelings" (5: 205). Human feelings, here, manifest themselves violently, and the victim of this violence that which is violated - is the object, the thing that is external to the human subject. For Ruskin, the "falseness" of the pathetic fallacy comes from the perceiver projecting their own emotional state onto the natural world. He offers, as example, two lines from Oliver Wendell Holmes's Astrea:

The spendthrift crocus, bursting through the mould Naked and shivering, with his cup of gold. (5: 204)

"This is very beautiful, and yet very untrue," Ruskin complains; "The crocus is not a spendthrift, but a hardy plant; its yellow is not gold, but saffron" (5: 204). In "Of the Pathetic Fallacy," then, Ruskin aims to differentiate between the "ordinary, proper, and true appearances of things to us" and the "false appearances" which are "entirely unconnected with any real power or character in the object, and only imputed to it by us" (5: 204). ${ }^{4}$ For Ruskin, projecting human characteristics into objects - projecting, as it were, a kind of emotional interiority or subjectivity into nonhuman things like crocuses - is a failure to recognize what he calls the "real power" inherent in those objects. The pathetic fallacy is a kind of misreading. Or, rather, it is a forced reading-into. It results from a misunderstanding about the location of power in the subject-object relationship.

Indeed, it's important to note that Ruskin launches his critique of the pathetic fallacy by taking issue with the discourse of perception in philosophic debates about subjectivity. The first object of his attack is the problem of taste - a central concern in philosophy ever since Kant depicted taste as dependent upon an individual's unique taste organs: "a man may recount to me all the ingredients of a dish, and observe of each and every one of them that it is just what I like, and, in addition, rightly commend the wholesomeness of food; yet I am deaf to all these arguments. I try the dish with my own tongue and palate, and I pass judgment according to their verdict (not according to universal principles)" (158). Hume similarly rejects the idea that universal principles might govern taste, arguing instead that it is "fruitless" to "pretend to ascertain the real sweet or real bitter. According to the disposition of the organs, the same object may be both sweet and bitter" (I.XXIII.8). As Luc Ferry has written, taste comes to represent "the very essence of subjectivity, the most subjective within the subject" (10). It is precisely this subjectivity that Ruskin takes to task. He parodies the stance of "troublesome metaphysicians" like Hume who locate the realities of perceptual experience in subjectivity: "To be sweet, [they say,] a thing must have a taster; it is only sweet while it is being tasted, and if the tongue had not capacity of taste, then the sugar would not have the quality of sweetness" (5: 201). Ruskin finds this model of subjectivity troubling because it allows for the threatening existence of "qualities of things which thus depend upon our perception of them" (5:201): "From these ingenious views, the step is very easy to a farther opinion, that it does not matter what things are in themselves, but only what they are to us; and that the only real truth of them is their appearance to, or effect upon, us" (5: 202). He is offended by the idea that the true qualities of any "thing" - sugar, in this case, and its quality of sweetness - might depend upon our perception of it. Who is the agent in such a complex relationship: the sugar, or the taster? 
For Ruskin, the problem of taste serves to exemplify the dangers of theories of perception that privilege relativism and subjectivity. In his rebuttal, he insists upon the "power" of the tasted object to produce a standard sensation:

I derive a certain sensation, which I call sweetness, from sugar. That is a fact. Another person feels a sensation, which he also calls sweetness, from sugar. That is also a fact. The sugar's power to produce these two sensations, which we suppose to be, and which are, in all probability, very nearly the same in both of us, and, on the whole, in the human race, is sweetness. (5: 203n)

In order to reject a relativist model of perception, Ruskin dramatically effaces the role of the perceiver. He places his faith instead in the universal, non-negotiable qualities of the object, the thing that is perceived. For Ruskin, these qualities constitute power. As Miller notes, Ruskin's insistence on externality serves his larger goal in Modern Painters: if things possess intrinsic properties that may be perceived, then they "may therefore be literally and truly named in poetry or represented in art" (400). Indeed, when Ruskin turns to the problem of vision - the perception of color when viewing a blue flower called a gentian - he continues to locate "power" in objectivity:

Now, to get rid of all these ambiguities and troublesome words at once, be it observed that the word blue does not mean the sensation caused by a gentian on the human eye; but it means the power of producing that sensation: and this power is always there, in the thing, whether we are there to experience it or not, and would remain there though there were not left a man on the face of the earth. (5: 202)

And, lest we think he uses the word "power" casually, Ruskin's next simile underscores its connotation of physical potency: "Precisely in the same way gunpowder has a power of exploding. It will not explode if you put no match to it. But it has always the power of so exploding, and is therefore called an explosive compound, which it very positively and assuredly is, whatever philosophy may say to the contrary" (5: 202). Like unexploded gunpowder, he argues, an unlooked-at gentian doesn't produce any sensation of blueness, but "it has always the power of doing so; its particles being everlastingly so arranged by its Maker" (5: 202). If you somehow how fail to see gentians as blue, "it is not their fault but yours" (5: 202).

The pathetic fallacy, then, is a failure to recognize the intrinsic power of objects, an attempt to read dependency into the independence of the perceived thing. But such a celebration of objective reality has profound consequences for Ruskin's model of perception: it effectually grants the object complete autonomy in the perceptual exchange. When you perceive an object, Ruskin seems to imply, you are merely being acted upon by it; you turn yourself over to it; you may perceive, but it $i s$. The viewer is subject to the gentian and its blueness, just as the taster is subject to the power of the sugar and its sweetness. In short, Ruskin's model of perception posits a kind of radical objectivity in which things possess what political ecologist Jane Bennett calls "vitality": the capacity "not only to impede or block the will and designs of humans but also to act as quasi agents or forces with trajectories, propensities, or tendencies of their own" (viii). ${ }^{5}$ From this angle, "Of the Pathetic Fallacy" can be read as form of Victorian object theory, a reading of the world that destabilizes the centrality of human subjective experience and locates instead a power independent of human 
experience in objects and things. To read Ruskin in this way is somewhat counterintuitive; as Mark Frost notes, Ruskin can hardly be considered a materialist (14). ${ }^{6}$ Yet the aim of much object theory - to minimize the difference between subjects and objects, to elevate what Bennett calls the "shared materiality of all things" (13) - is not incompatible with Ruskin's own drive, in "Of the Pathetic Fallacy," to critique the anthropocentric impulse to overwrite objective reality with human subjectivity. Bennett is similarly resistant to readings that prioritize the human: "The philosophical project of naming where subjectivity begins and ends is too often bound up with fantasies of a human uniqueness in the eyes of God, of escape from materiality, or of mastery of nature" (ix). Ruskin may not take to task the fantasy of human uniqueness, but "Of the Pathetic Fallacy" makes clear that imposing our own emotions onto inanimate objects is an attempt to master nature, to wrest from nonhuman things their intrinsic power. ${ }^{7}$

Yet for the purposes of this paper, Ruskin's language of powerful things is primarily interesting not because of its engagement with ecological discourse but rather because of the way it intervenes in an increasingly important conversation about the nature of the Victorian object and the way we read (or misread) it. Long-nineteenth-century literature, both British and American, has proved an especially fruitful site for critics intent on reimagining the nature of the thing. This fruitfulness stems partly from the fact that the nineteenth century, and the Victorian period especially, has long been associated with the rise of commodity culture. As critics such as Elaine Freedgood and John Plotz have noted, Victorian literature (the novel in particular) is awash in things. Object theory asks us to return to those nineteenth-century things in order to contend, as Brown does, that nonhuman objects are not always reducible to commodities (Sense 13). Contemporary theorists like Brown draw distinctions between objects and things, a distinction that Ruskin himself does not make. Brown writes that objects become things when they "stop working for us": "you cut your finger on a sheet of paper, you trip over some toy, you get bopped on the head by a falling nut" ("Thing Theory" 4, 3). Ruskin, instead, is invested in things that intervene materially in much subtler ways: an object or thing rejects our dominion when it asserts its "real power or character" over and against our interpretation of it, when it refuses to be read into. And yet Ruskin's model of sugar and gentians as powerful things - one a man-made commodity, one decidedly not - demonstrates a Victorian way of conceiving objects that locates in them an effectivity independent of human culture. For Ruskin, the human subject is subject to the object. To be like a thing in Ruskin's discourse of perception is to possess a vital ability to control and delimit perception.

\section{Rossetti's radical objectivity}

RUSKIN'S POWERFUL THINGS RESIST anthropomorphism and, in so doing, they insist on objective independence: human mouths may be able to appreciate the sweetness of sugar, but they play no role in constituting it. Untasted sugar is as sweet as tasted sugar. We see a similar attempt to destabilize anthropocentric models of the natural world in Christina Rossetti's early devotional poem, "To what purpose is this waste?":

The ripest plum down tumbled to the ground By southern winds most musical of sound, But by no thirsty traveller found: Honey of wild bees in their ordered cells 
Stored, not for human mouths to taste:-

I said, smiling superior down; What waste

Of good, where no man dwells. $(1-31)^{8}$

In this early poem, Rossetti's aim is to critique a human-centered understanding of God's creation. The narrator's smug superiority is soon replaced with an appreciation of nonhuman nature: the "tiniest living thing," she comes to realize, "Has just as good a right / To its appointed portion of delight / As any King" (87-89). Yet the central query of this stanzawhat becomes of the ripeness of plums if they are never tasted by human mouths? - is one that Rossetti returns to in more complex form in "Goblin Market." "To What Purpose Is This Waste?" ultimately imagines another mouth to consume the ripe plum, the mouth of an animal or insect. Not so "Goblin Market": its natural world is peculiarly devoid of animals and insects. There are goblins, of course, but they are explicitly quasihuman; the poem is concerned with them as peddlers, not consumers. The only nonhuman creatures that seem to eat are the animals the sisters tend on their farm. Unlike the early devotional poem, "Goblin Market"'s sumptuously rendered world of edibles imagines no potential consumer other than the human mouth: the ripe plum's contract is with it, or with nothing. Such a contract raises the stakes of the human-object relationship. Without recourse to the nonhuman mouth as taster, Rossetti's challenge to models of perception as subjective must necessarily be more radical: what might the power of an object be without any perceiver at all? In this next section, I want to consider "Goblin Market" as an experiment in Ruskinian object theory in order to reconsider the poem's complex treatment of perception. Rossetti asks the same questions as Ruskin: Is sugar sweet if you don't open your mouth? Does it in fact exist if you don't taste it?

Reading for questions such as these allows us to attend to the ways the poem's depiction of economic exchange mirrors its depiction of perceptive exchange. Economic readings of the poem focus on the dangers of commodity culture: Laura, who barters a golden curl for the fruit, commodifies her body in order to enter the economic market; Lizzie, attempting to buy the fruit her sister so desperately craves, is armed instead with a silver coin, but she doesn't actually spend it. In the end, she beats the goblin men at their own game: refusing to taste the fruit herself, she manages to bring some home to Laura when the enraged goblins smear it on her body. Laura kisses her sister, tastes the fruit, and this time it works as a powerful antidoteLaura is cured. Lizzie's relationship to economic exchange, then, is complex: she offers to pay, but doesn't; she refuses to consume the fruit, but she willingly transports it; and although she rejects commodifying her body like lock-trading Laura, Lizzie turns her own body into a conduit for exchange by using it to deliver the fruit to her sister. Lizzie's participation in this economy, in other words, is very carefully navigated. This same complexity is at work in Lizzie's participation in the economy of perception. Indeed, the poem works to link the dangers of material consumption to those of sensory perception. Early in the poem, when Laura and Lizzie first encounter the goblins singing their fruit-merchant jingles, the sisters are differentiated by the way they respond to these sights and sounds: Laura "reared her glossy head," while "Lizzie covered up her eyes, / Covered close lest they should look" (501-51). The worldliness of the goblins thus appears as a temptation of sense perception that is best avoided by withdrawal: Lizzie's first escape occurs because she "thrust a dimpled finger / In each ear, shut eyes and ran" (67-68). Later, when she returns to the goblins in search of fruit for her ailing sister, she begins by simply perceiving them: "for the first time in her life," Rossetti writes, Lizzie "Began to listen and look" (327-28). In this way Lizzie's controlled 
entry into the market is paralleled by her movement from willful blindness and deafness to active listening and looking - perceptive acts that have been shown, via Laura's cautionary tale, to threaten the body of the perceiver.

Yet these threats are more complex than we might think. Perception, "Goblin Market" suggests, is dangerous not because it opens you up to the world - not because it renders you a participant in the perceptive economy of goblin-marketing - but rather because it isolates you from it. Laura's tasting leads to blindness and deafness: once she's eaten, she suddenly finds that she can no longer hear the cry of the goblins advertising their fruit. ${ }^{9}$ Lizzie, who did not partake, still hears them; but the narrator's focus stays on Laura, who "turn'd cold as stone / To find her sister heard that cry alone" (253-54). In a poem that has gone to great lengths to make the sisters nearly indistinguishable,${ }^{10}$ the word "alone" is striking here. For the first time, Laura is isolated from her sister. What is more, Rossetti describes Laura's isolation explicitly as a sensate one, removing her from perceptive exchanges: "Must she then buy no more such dainty fruit? / Must she no more such succous pasture find, / Gone deaf and blind?" (258-59). When Laura eats the fruit of the goblin men, in other words, it changes her subjective experience of the world by isolating her, cutting her off from the avenues of perception she formerly shared with her sister. Rather than embroiling Laura in worldly exchange, tasting effectively removes her from circulation.

Laura's fall, then, is less a fall into the market - into a world of exchange that ultimately objectifies her - than it is a fall into subjective perception. As Kathy Psomiades has noted, Laura's consumption of the fruit makes her "a creature of depth and surface" with secret desires and longings, thus granting her a kind of interior subjectivity that she did not have before (50). Laura is subjectified, as it were. The perceptive exchange appears as a kind of reverse pathetic fallacy: instead of the perceiver projecting human interiority into the object, the object seems to reflect interiority into the perceiver. In the language of Ruskin's powerful things, Laura ends up subject to the object. Moreover, this granting of interiority appears to trap Laura in her own subjectivity. And it's no coincidence, I think, that Rossetti implicates the discourse of taste in Laura's isolation. The taste of the exotic goblin fruits is incomparable, Rossetti suggests: "She never tasted such before, / How should it cloy with length of use?" (132-33). It is this isolated and isolating experience that grants the fruit its power over Laura: it cannot ever cloy, ever satiate, because it is so unique. Taste, here, cannot be compared - even Laura herself has nothing to compare it with. This is an extreme version of the Kantian problem of taste to which Ruskin objected: it provides no data for universal experience. As a result, Laura's incomparable consumption goes on to consume her in increasingly problematic ways. This is first intimated in her own account of her tasting (or, rather, her inability to provide an account of her tasting): "You cannot think what figs / My teeth have met in," she exclaims to Lizzie. The sweetness of the figs cannot be communicated: it's a fall into the very subjective relativism Ruskin so disdained, a world in which qualities of sweetness and taste cannot be truly represented in art or language.

Taste, for Rossetti as well as for Ruskin, operates as a kind of shorthand for a model of perception as subject-determined, contingent, relative. In "Goblin Market," Rossetti constructs an economy of perception in which the seemingly active subject becomes dependent upon the material object: Laura's craving for the goblin fruit renders her helpless, pining for a perceptual experience she has no power to replicate. This is an economy of perception in which material objects possess the power to dictate how (and whether) they are perceived. But Rossetti's heroine turns this economy on its head by using it to her own 
advantage. When Lizzie seeks out the goblins to purchase fruit for her ailing sister, she rejects her role as subject in the perceptive economy of taste. Refusing to taste the fruit, Lizzie refuses being read into - refuses, as it were, becoming like the shivering spendthrift crocus of Ruskin's pathetic fallacy, or like her sister, languishing in her interiority. And in refusing the subjectivity of the taster, Lizzie is able to remain in circulation: "Lizzie uttered not a word; / Would not open lip from lip / Lest they should cram a mouthful in" (430-32). As Psomiades notes, Lizzie's refusal of the goblin fruit privileges surface over interior: her body "does not point to any hidden depth of meaning: it is the meaning; its meaning is to have fruit all over it" (50). Another way of thinking about this privileging of surface is that Lizzie rejects the isolating subjectivity of taste and claims instead the radical power of the object: the goblin fruit itself.

By refusing to taste the goblin fruit - by turning her own body into an object for the transmission of the fruit-antidote Laura needs to survive - Lizzie enacts an extreme version of Ruskin's postulate about the power of the object. For indeed, when she returns to her sister dripping with the juices of the goblin fruit, the seemingly universal, non-negotiable qualities of the object have in fact altered: the goblin fruit is no longer sweet to Laura. Now it is bitter: "Her lips began to scorch, / That juice was wormwood to her tongue, / She loath'd the feast" (493-94). Lizzie's rejection of taste destabilizes the inherent power of the goblin fruit as she claims that objectivity for herself. ${ }^{11}$ In the poem's economy of perception, tasting changes the subject (Laura can no longer hear the goblins), but not tasting changes the object (the fruit was sweet poison, now it's bitter antidote). By refusing subjectivity, Lizzie is able to dictate how objects are perceived. Lizzie's controlled entry into the economy of perceptual exchange is not exactly a withdrawal; instead, she enters the world of material objects as a circulating object herself, and claiming the radical powers of objectivity.

\section{Beyond the market}

I'VE BEEN ARGUING THUS far that considering Ruskin's model of powerful things allows us to see the ways Rossetti is playing with economies of perception in "Goblin Market," experimenting with a form of radical objectivity in which the power to delimit perception and stabilize meaning lies not with the perceptive body but with the object it perceives. Like Ruskin's “Of the Pathetic Fallacy,” Rossetti's poem imagines objecthood as a position of surprising agency. But such a formulation depends on an economy of perception that deprivileges relativism and subjectivity - that deprivileges, in other words, any dependence of the thing that is perceived upon the subject that perceives it. In Ruskin, this means rejecting anthropomorphism, which figures as an act of interpretive violence against the intrinsic power of the object. In Rossetti's world, it often means something more complex: reassessing what it means to objectify a subject, to grant the powers of radical objectivity to the human body. Attending to this radical objectivity is important because it allows us to see the ways in which Rossetti challenges, perhaps unexpectedly, the easy alignment of objectification with passivity and commodification. In much recent work on materiality and embodiment in the Victorian period, bodies become things when they enter commodity culture. ${ }^{12}$ But in "Goblin Market," we have a body that operates as a thing without becoming part of the exchange network. ${ }^{13}$ In other words, Rossetti's poem gives us a way of conceiving of thingly bodies as something other than commodities. To be a commodity is dangerous; but to be a thing, stubbornly independent, is to be surprisingly powerful. 
How might this distinction play out elsewhere in Rossetti's body of writing? One text that provides an especially provocative counterpoint is "Hero: A Metamorphosis," a short story composed not long after "Goblin Market" and yet rarely considered alongside it. ${ }^{14}$ In fact, the two texts have much in common. Like "Goblin Market," "Hero" tells the tale of an innocent maiden who oversteps the prescriptive bounds of female desire and undergoes a perilous transformation; like "Goblin Market" it ends with the maiden, now grown, recounting the moral of her story to her children. But where Laura's fall hinged on her desire to consume, to taste, Hero's is founded on her desire to be the object of consumption: Hero wishes to become "the supreme object of admiration," a wish that results in a series of surprising metamorphoses. Both narratives explore the question of what it means to be perceived, the relationship between subjectivity and objectivity, and the remarkable degree to which subjects can become objects and vice versa. But whereas "Goblin Market" grants the perceived object power over the perceiver, "Hero" does the opposite. In "Hero" we see dramatized for us the perils of a world in which objective stability is drastically undermined by subjective perception; and it's no coincidence, I think, that the story's destabilized objects function as commodities, their worth dependent entirely upon the taste of the perceiver. "Hero" moves beyond taste as physical sensation in order to explore larger questions of subjectivity and power in aesthetic judgment.

As John Plotz has noted, "Hero" reads like a Victorian revision of the eighteenth-century talking-object narrative - except this time, "rather than a coin speaking and feeling as a person would, the opposite happens: a person becomes a coin-like object" (31). The imagined world of "Hero" maps the geography of Fairyland, separated from the human world (peopled by "a bold tribe of semi-barbarous fishermen") by an arm of the sea (184). Objects from Fairyland occasionally wash ashore on the human side, from precious gems and delicate metalwork to bejeweled starfish or branches of "unfading seaweed, exquisitely perfumed" (184). As in "Goblin Market," though, such treasures are not visible to all: only "children and innocent young maidens" can discover them (185). One such maiden is Hero. One day, however, Hero begins to doubt the love of her father, Peter Grump, and her fiancé, Forss. She withdraws into herself, much like Laura does after tasting the goblin fruit: her expression loses its "gay sweetness," she sings "snatches of plaintive or bitter songs," and - perhaps most troubling of all - the treasures of Fairyland seem no longer to be visible to her (188). Sadly, Hero has no sister there to save her, so she chooses instead to objectify herself. As a reward for rescuing the Princess Royal of Fairyland, Hero is granted one wish, and she asks to "become the supreme object of admiration" wherever she goes (190). The Fairy Queen grants the wish begrudgingly, warning Hero: "I cannot ennoble the taste of those who look upon you: I can but cause that in you all desire shall be gratified" (193). What's important to note here is that Hero's request is made Faustian by its deliberately slippery terms of perception and agency: the Fairy Queen's language renders Hero not the actor but rather the acted-upon. Hero assumes she will be gaining power as a result of this transaction - that, as the supreme object of admiration, she will dictate the terms of her perception by causing everyone to admire her. However, as Hero's narrative makes clear, the reverse turns out to be the case: Hero is forced to repeatedly change shape, dependent upon the taste of those who perceive her.

Hero's objectification, then, is profoundly different than Lizzie's. Lizzie's radical objectivity granted her agency and independence within the economy of perception; Hero's, on the other hand, renders her completely dependent. Where Lizzie thwarted commodification and exchange, Hero embodies it. Upon the granting of her wish, Hero's "conscious spirit" 
is removed from her body, which is left in the keeping of the Fairy Queen, and "charmed" into a "heavy blazing diamond" (195). ${ }^{15}$ The jewel's dazzling beauty immediately provokes conflict that escalates to violence and death as men fight for possession; the diamond is eventually claimed by a brutal murderer and spirited away for sale. Rossetti dwells on Hero's status as a commodity: "when she heard the sums running up from thousands into millions which whole guilds of jewelers, whole caravans of merchant princes, whole royal families clubbed their resources to offer for her purchase, it outweighed all she had undergone of disgust and tedium" (196). ${ }^{16}$ As a diamond, then, Hero's desire to be desired seems satisfied: she herself is bored and passive, but she takes pleasure in knowing what she is worth. Yet the story doesn't leave her here. In fact, Hero's metamorphoses do not trace a linear trajectory from human agent to passive object. Instead, she moves back and forth between the two categories. Purchased as part of a royal marriage settlement, Hero soon changes shape again when the bridegroom admires his bride more deeply than her jewel; when a beautiful singer, Melice, next attracts the man's attention, she transforms yet again. But when Melice quits her adoring fans and departs for her uncle's remote village, Hero's metamorphoses become less glamorous. Melice's Uncle Treeh (who himself already seems both human and nonhuman: "he strikingly resembled certain plants of the cactus tribe, which, in turn, resemble withered old men") has eyes only for his beloved plants, and soon Hero is humiliated to find herself transformed into a seed burrowing into the soil (202). When the old man dies, his property is turned over to new owners whose taste, as the Fairy Queen predicted, is less noble Hero might have desired. "These useless buildings must be cleared away," a richly attired woman declares; "This will be the exact spot for a ruin: I adore a ruin!" (207). At this point Hero's spirit "die[s] in the slighted plant," unwilling to condescend to court such admiration (207). As in "Goblin Market," "taste" is dangerously subjective - only here, the problem is not the impossible-to-describe mouthfeel of fruit but rather the impossible-to-improve aesthetics of personal desire. In "Hero," taste itself cannot be "ennobled"; rather, the object itself changes in order to accommodate it. Instead of radical objectivity, "Hero" gives us a world of radically destabilizing subjectivity.

Why, then, this difference? Why, in two such similar narratives, does Hero's objectification so utterly deprive her of agency while Lizzie's empowers her? To my mind, these two texts provide two different models for imagining objectified women - one as a stubbornly independent thing and one as a dependent object or commodity. And here is where I find Bill Brown's distinction between objects and things to be especially useful in articulating Lizzie's and Hero's fates. Objects become things, Brown writes, when they "stop working for us." In Rossetti's world, this distinction hinges on the balance of power and dependence in the subject-object relationship. A thing is powerful when it refuses to be read into; when it is stubbornly opaque; when it establishes authority over its perceiver. Hero, on the other hand, has no power as an object because she never "stops working for" her perceivers, never frustrates or fails to accommodate their shifting aesthetic desires. Hero's objectification is grounded in commodification, her value dependent entirely upon her perceiver. What is more, this kind of objectification comes at the price of disembodiment. Lizzie remains fully embodied: as the goblins attack her, she laughs to "feel the drip / Of juice that syrupped all her face, / And lodged in dimples of her chin, / And streaked her neck which quaked like curd" (433-36). Hero, divorced from body and dependent on taste, is repeatedly overwritten. The problem is not actually that Hero becomes like a thing; rather, the problem is that she is not thinglike enough. 
To read this way is to read athwart our tendency to deprivilege objectivity - to uneasily accept Rossetti's tendency to associate agency with states of being that don't look much like agency to us at all. Taken to the extreme, of course, a doctrine that preaches the power of the thingly body might go in strange places - as indeed it does elsewhere in Rossetti's oeuvre. Among her most discussed works are her corpse poems, which have disconcerted generations of critics by locating a form of authority and independence in the dead body. These poems give us postmortem narrators, subjects who explicitly metamorphose from humans into objects. Diana Fuss notes the "curious paradox" of the corpse poem: "A poem implies subjective depth while a corpse negates interiority" (1). As many critics have noted, Rossetti's curiously desubjectified speakers seem to narrate from a position of power. Anne Jamison, for example, sees in "After Death" "the triumph of the female corpse": "it is the surviving male who is blinded (unable to see that he is being watched and heard), watery (weeping) and silenced, while the female corpse watches, listens, interprets, and speaks through the poem" (266). ${ }^{17}$ Moreover, the speaker in "After Death" can now dictate the terms of her reception: "He did not love me living; but once dead / He pitied me; and very sweet it is / To know he still is warm tho' I am cold" (12-14). Contrast this speaker's position with that of the artist's model in "In an Artist's Studio," another poem that grapples explicitly with imbalances of power in the dynamics of perception. In this poem, the power of the subject over the object is depicted as predatory, even vampiric: the painter "feeds upon" his model (9). Indeed, the model's disenfranchisement seems to stem from the fact that perception, actual perception, has failed entirely: the painter is blinded by his own vision of the woman, painting her over and over "Not as she is, but as she fills his dream" (14). And this misreading, as it were, obliterates her actual presence, reducing her to "[t]he same one meaning, neither more nor less" (8). The painter here commits the cardinal sin of Ruskin's pathetic fallacy: he violates the object via a forced reading-into. The artist's model is deprived of control over how she is perceived, whereas the dead speaker in "After Death" retains it. Speaking, as it were, from the position of a thing - for what can better exemplify a body that has "stopped working for us" than a corpse? - seems to be one way of resisting being read into. ${ }^{18}$

What I'm proposing here is not the key to all mythologies; given Rossetti's immensely multifaceted corpus, I am skeptical that such a key exists. Instead I have wanted to use Ruskin's and Rossetti's experimentation with radical objectivity to query the relationship of Victorian objects to Victorian discourse about perception, subjectivity, and embodiment. Indeed, if Victorian fiction is notable for being overpopulated with things, what do we make of Victorian poetry's relationship to objects and to objectivity? Ruskin's resistance to the pathetic fallacy - and Rossetti's exploration of the terms and stakes of such resistance suggests that Victorian poets were debating the nature of objects (and their relationship to human subjects) in provocative ways.

\section{Albion College}

\section{NOTES}

1. Terrence Holt's 1990 essay was one of the first to make the case that economic readings of the poem might "resolve some of the issues that have troubled readings focused on gender" (51). Holt, for 
example, sees the poem as a utopian fantasy that attempts (and ultimately fails) to imagine a "position for women outside systems of power" (51), whereas Elizabeth Campbell's article of the same year argues instead that the poem accomplishes just that in its celebration of maternity.

2. Similarly, in Richard Menke's reading, Lizzie is rewarded for resisting commodity fetishization: "without becoming either the subject or the object of exchange, Lizzie transforms pure exchangevalue (the commodity of goblin fruit) into pure use-value (the "fiery antidote' that saves Laura)" (128).

3. Mary Wilson Carpenter also reads the poem as celebrating, albeit in a qualified way, the female appetite: "The female body in the poem is subject to 'consumption' as a commodity' - as Laura's near fatal experience demonstrates - but it is also 'consumable as a regenerative and self-propagating 'fruit,' as Lizzie's example shows us" (416).

4. J. Hillis Miller writes of the extremity of Ruskin's stance on personification, surely one of the most fundamental tropes in poetry: "Ruskin's fierce puritan rejection of the worship of graven images, idolatry, is prepared to give up even poetry in the name of truth. ... His fundamental motivation is to find and praise a beauty which is also true" (401).

5. Following Latour, Bennett argues in her book Vibrant Matter for the "material agency or effectivity of nonhuman or not-quite-human things" in order to challenge the anthropocentrism of political theory: "my hunch is that the image of dead or thoroughly instrumentalized matter feeds human hubris and our earth-destroying fantasies" (ix).

6. Frost argues that Ruskin's full rejection of materialist thought did not occur until his disillusionment with Darwinian science in the 1870s; before then, Frost writes, his engagement with ecological thought demonstrated a complex alertness to the "dynamic materialities of environment" (14). Frost locates crucial moments in Ruskin's corpus (a lecture on rusted iron, an essay on moss) that attend to "a realm of interdependence and belonging for humankind within the economy of organic life" (21). Other critics such as Sara Atwood have similarly helped to elucidate the organicism of Ruskin's view of the natural world, which sees humanity as deeply and reciprocally intertwined with nature. As Ruskin wrote in The Ethics of the Dust: "Things are not either wholly alive, or wholly dead. They are less or more alive" (18: 346).

7. For more on the relationship between anthropomorphism and ecology, see Lawrence Buell's The Future of Environmental Criticism and Lorraine Daston and Gregg Mitman's Thinking with Animals.

8. The poem was composed in 1853 , though it was not published until the 1890 s.

9. Along similar lines, Carpenter notes that the poem does not actually condemn voyeurism, despite its seeming critique of Laura's looking: "While one can get into trouble by satisfying the desire to look and listen, the trouble is precisely the loss of that desire" (427).

10. See, for example, one of the poem's famous extended similes:

Golden head by golden head,

Like two pigeons in one nest

Folded in each other's wings,

They lay down in their curtain'd bed:

Like two blossoms on one stem,

Like two flakes of new-fall'n snow,

Like two wands of ivory

Tipp'd with gold for awful kings. (184-91)

11. Albert Pionke reads this transmutation similarly: "Lizzie's active resistance to the goblins during her own second encounter with them has altered the meaning of Laura's second fall by radically shifting the terms of exchange - she has effectively reimagined the market, not as an abstracted cash nexus, nor as a system of barter, but as a gift economy" (903). However, I think we can't overlook the oddity of this particular gift: rather than simply purchase fruit and bring it to her sister, Lizzie transforms her 
body itself into the gift object, as is evidenced in her command to Laura: "Hug me, kiss me, suck my juices" (468).

12. Katharina Boehm's recent edited collection makes this clear: "Throughout the nineteenth century, the body and its individual parts were given object-status when they were sold, bought, exhibited, collected, and exchanged" (6).

13. As Menke notes, "Lizzie saves but never spends, never consummates an exchange" (128).

14. "Hero" originally appeared in the Argosy in January 1866 and was later published in the collected volume Commonplace and Other Short Stories in 1870. The vexed publication history of that collection is visible in The Letters of Christina Rossetti, Vol. 1; Anthony H. Harrison speculates that Rossetti had sent a draft of "Hero" to Alexander Macmillan as early as February 1861 (Letter 132). Very little critical attention has been paid to the tale, although Dante Gabriel was evidently a fan: "Your 'Hero' is splendid," he told Christina, "you ought to write more such things" (qtd. in Packer 269). John Plotz provides the most sustained analysis of the text I have been able to find in his chapter on diamond plots in Portable Property (24-44).

15. The Fairy Queen explains these terms to Hero, making clear that her body will be preserved as a kind of safeguard: "I am my trusty counsellors have agreed for one year to retain your body here, whilst in spirit you at will become one with the reigning object of admiration" (194).

16. Plotz argues that in Victorian literature, diamonds function as boundary-troubling "things" in their "persistent refusal to turn either into pure liquidity or pure bearers of sentimental value" (25).

17. Jamison notes that "Rossetti's corpses, like the poems that form them, give little away, tending rather to obscure what they seem to set out to disclose" (260).

18. Rossetti provides an interesting counterpoint in "Nick," the story immediately preceding "Hero" in Commonplace. Like Hero, Nick enters into a fairy bargain that results in repeated physical transformations (for Nick, these are punishment for the avarice and ill will he displays toward his neighbors). Nick's climactic metamorphosis transforms him into a corpse, about to be buried by his murderers. Here the corpse position is one of uncanny impotence: "An utter horror seized him, while, at the same time, he felt a strange consciousness that his hair would not stand on end because he was dead" (178). Nick is saved only by being transformed into his own living body again, frightening the murderers away before they can finish burying him. In this economy, the position of corpse holds no special powerperhaps because, like Hero, Nick's objectification is also contingent upon disembodiment.

\section{WORKS CITED}

Atwood, Sara. “"The Earth-Veil: Ruskin and Environment.” Journal of Pre-Raphaelite Studies 24.3 (Spring 2015): 5-24.

Bennett, Jane. Vibrant Matter: A Political Ecology of Things. Durham: Duke UP, 2010.

Boehm, Katharina. Bodies and Things in Nineteenth-Century Literature and Culture. New York: Palgrave Macmillan, 2012.

Brown, Bill. A Sense of Things: The Object Matter of American Literature. Chicago: U of Chicago P, 2003.

Brown, Bill. "Thing Theory." Critical Inquiry 28.1 (Autumn 2001): 1-21.

Buell, Lawrence. 2005. The Future of Environmental Criticism: Environmental Crisis and Literary Imagination. Malden, MA: Blackwell.

Campbell, Elizabeth. "Of Mothers and Merchants: Female Economics in Christina Rossetti's 'Goblin Market."” Victorian Studies 33.3 (Spring 1990): 393-410.

Carpenter, Mary Wilson. “'Eat me, drink me, love me': The Consumable Body in Christina Rossetti's 'Goblin Market." Victorian Poetry 29.4 (Winter 1991): 415-34.

Daston, Lorraine and Gregg Mitman (eds). 2005. Thinking With Animals: New Perspectives on Anthropomorphism. New York: Columbia UP. 
Ferry, Luc. Homo Aestheticus: The Invention of Taste in the Democratic Age. Trans. Robert de Loaiza. Chicago: U of Chicago P, 1993.

Freedgood, Elaine. The Ideas in Things: Fugitive Meaning in the Victorian Novel. Chicago: U of Chicago P, 2006.

Frost, Mark. "The Everyday Marvels of Rust and Moss: John Ruskin and the Ecology of the Mundane." Green Letters 14.1 (2011): 10-22.

Fuss, Diana. "Corpse Poem.” Critical Inquiry 30.1 (Autumn 2003): 1-30.

Helsinger, Elizabeth K. "Consumer Power and the Utopia of Desire: Christina Rossetti's 'Goblin Market.'” ELH 58.4 (Winter 1991): 903-33.

Holt, Terrence. “'Men sell not such in any town': Exchange in Goblin Market." Victorian Poetry 28.1 (Spring 1990): 51-67.

Hume, David. "Of the Standard of Taste." Essays, Moral, Political, and Literary. www.econlib.org. Ebook. Jamison, Anne. "Passing Strange: Christina Rossetti's Unusual Dead.” Textual Practice 20.2 (2006): 257-80.

Kant, Immanuel. Critique of Judgement. $2^{\text {nd }}$ ed. Trans. J. H. Bernard. London: Macmillan, 1914.

Kooistra, Lorraine Janzen. "Visualizing the Fantastic Subject: Goblin Market and the Gaze." The Culture of Christina Rossetti. Ed. Mary Arseneau, Antony H. Harrison, and Lorraine Janzen Kooistra. Athens: Ohio UP, 1999. 137-69.

Lysack, Krista. Come Buy, Come Buy: Shopping and the Culture of Consumption in Victorian Women's Writing. Athens: Ohio UP, 2008.

Menke, Richard. "The Political Economy of Fruit: Goblin Market." The Culture of Christina Rossetti. Ed. Mary Arseneau, Antony H. Harrison, and Lorraine Janzen Kooistra. Athens: Ohio UP, 1999. 105-30.

Miller, J. Hillis. "Catachresis, Prosopopoeia, and the Pathetic Fallacy: The Rhetoric of Ruskin." Poetry and Epistemology: Turning Points in the History of Poetic Knowledge. Ed. Roland Hagenbüchle and Laura Skandera. Regensburg: Pustet, 1986. 398-407.

Packer, Lona Mosk. Christina Rossetti. Berkeley: U of California P, 1963.

Pionke, Albert. "The Spiritual Economy of 'Goblin Market." Studies in English Literature 52.4 (Autumn 2012): 897-915.

Plotz, John. Portable Property: Victorian Culture on the Move. Princeton: Princeton UP, 2008.

Psomiades, Kathy. Beauty's Body: Feminism and Representation in British Aestheticism. Stanford: Stanford UP, 1997.

Rossetti, Christina. “After Death.” The Complete Poems. Ed. R. W. Crump. London: Penguin, 2001. 31-32.

Rossetti, Christina. "Goblin Market.” The Complete Poems. Ed. R. W. Crump. London: Penguin, 2001. 5-20.

Rossetti, Christina. "Hero: A Metamorphosis." Commonplace and Other Short Stories. London: F. S. Ellis, 1870. 181-211.

Rossetti, Christina. “In an Artist's Studio.” The Complete Poems. Ed. R. W. Crump. London: Penguin, 2001. 796.

Rossetti, Christina. Letter 132: To Alexander Macmillan, 12 February 1861. The Letters of Christina Rossetti, Vol. 1: 1843-1873. Ed. Anthony H. Harrison. Charlottesville: U P of Virginia, 1997. 143-44.

Rossetti, Christina. "Nick." Commonplace and Other Short Stories. London: F. S. Ellis, 1870. 165-179.

Rossetti, Christina. "To what purpose is this waste?" The Complete Poems. Ed. R. W. Crump. London: Penguin, 2001. 740-44.

Ruskin, John. The Complete Works of John Ruskin. 39 vols. Ed. E. T. Cook and Alexander Wedderburn. London: George Allen, 1903-12. 